\title{
DUKUNGAN UNTUK WANITA PENYANDANG DISABILITAS PADA AKUN INSTAGRAM @LIPSTICKUNTUKDIFABEL
}

\author{
Dinar Asvi Nurjannah, Yasinta Putri Wijaya dan Fakri Reza Kamrang \\ Universitas Pembangunan Nasional "Veteran" Jawa Timur, Indonesia \\ Email:dinarasviii@gmail.com, yasintawijayaa@gmail.com dan fakrireza@yahoo.com
}

\section{Abstract}

The purpose of this research is to dissect the Agenda Setting conducted by Instagram social media @lipsticuntukdifabel in order to support women with disabilities. This study uses agenda setting theory in analyzing the findings contained in this research. the results showed thatpeople with disabilities often assume that their shortcomings make them different from others. This often leads to a lack of confidence in people with disabilities, especially in their social environment, some people with disabilities tend to withdraw from social interactionsdue to lack of confidence. Various confidence supporting tools such as makeup become very important to be used in creating confidence for people with disabilities. In addition, factors fromoutside the social environment pa rapeople withdisabilities become an important factor insupportingthe confidence of people with disabilities.

Keywords: Disability; Agenda Setting; Instagram

\begin{abstract}
Abstrak
Tujuan penelitian ini adalah untuk membedah agenda setting yang dilakukan media sosial Instagram @lipsticuntukdifabel dalam rangka dukungan bagi wanita penyandang disabilitas. Penelitian ini menggunakan pendekatan metode penelitian kualitatif menggunakan teori agenda setting dalam menganalisis temuan yang terdapat pada riset ini. Hasil penelitian menunjukkan bahwa penyandang disabilitas sering menganggap bahwa kekurangan mereka membuat mereka berbeda dengan orang lain. Hal ini sering menimbulkan rasa kurangnya percaya diri pada para penyandang disabilitas terutama dalam lingkungan sosialnya, beberapa penyandang disabilitas cenderung menarik diri dari interaksi sosial karena kurangnya kepercayaan diri yang ada. Berbagai alat penunjang kepercayaan diri seperti make up menjadi hal yang sangat penting untuk digunakan dalam menimbulkan rasa percaya diri bagi kaum penyandang disabilitas. Selain itu, faktor dukungan dari luar lingkungan sosial para penyandang disabilitas menjadi faktor yang paling penting dalam menunjang rasa percaya diri kaum penyandang disabilitas.
\end{abstract}

Kata kunci: disabilitas; agenda setting; Instagram

Coresponden Author

Email: dinarasviii@gmail.com Artikel dengan akses terbuka dibawah lisensi 


\section{Pendahuluan}

Penggunaan media baru seperti smartphone semakin berkembang pesat, pengguna smartphone di Indonesia sekitar 100 juta pengguna smartphone aktif pada tahun 2018 menjadikan Indonesia sebagai negara dengan populasi pengguna smartphone terbesar keempat di dunia setelah China, India dan Amerika Serikat karena dengan smartphone, manusia dapat mengakses semua informasi yang ingin diperoleh termasuk belanja online (Untari \& Fajariana, 2018).

Bermunculannya berbagai aplikasi media sosial ini menimbulkan peluang bagi masyarakat dalam melakukan suatu usaha. Peluang terhadap media sosial tidak berhenti hanya pada usaha produk. Usaha jasa maupun pariwisata juga mulai menggunakan media sosial sebagai salah satu sarana untuk menarik perhatian masyarakat untuk menggunakan atau mendatangi destinasi objek wisatanya. Pada umumnya objek wisata menggunakan media sosial untuk menarik pengunjung dan memberikan informasiinformasi terkait dengan event-event yang akan diadakan kepada masyarakat. Pemanfaatan social media dapat berimbas positif bagi pencitraan obyek atau destinasi wisata (Indika \& Jovita, 2017).

September 2018 muncul sebuah akun instagram yang mempunyai nama @lipstickuntukdifabel. Akun Instagram tersebut mendadak populer di kalangan pengguna platform media sosial Instagram, terutama kalangan penggemar kecantikan atau biasa disebut beauty enthusiast. Akun Instagram ini ternyata dibuat oleh seorang beauty enthusiast berusia 27 tahun yang memiliki akun Instagram bernama @ heylaninka dan kemudian berganti menjadi @laninka karena diretas dan kini akun baru tersebut memiliki lebih dari 4000 pengikut. Selain memiliki akun Instagram tersebut, Laninka ternyata juga seorang beauty vlogger yang memiliki kanal YouTube bernama "The Wheelchair Girl" dan kini memiliki lebih dari 9.000 lebih subscribers. akun YouTube-nya tersebut Laninka sering mengunggah tutorial make up dan mendapat respon positif dari penontonnya. Tidak seperti beauty vlogger biasa, unggahan video pada kanal YouTube the Wheelchair Girl merupakan tutorial make up dan video log atau Vlog seorang wanita penyandang disabilitas.

Selain itu ada penelitian lain yang menyatakan bahwa media pemasaran online memberikan dampak terhadap terbentuknya minat beli konsumen (Balakrishnan, Dahnil, \& Yi, 2014). Hasil survei terhadap konsumen Cherie menunjukkan bahwa minat beli merupakan faktor yang paling dominan dalam mempengaruhi keputusan pembelian konsumen. Zaman modern yang sedang berkembang ini, media sosial tidak hanya digunakan sebagai media komunikasi, tetapi juga sebagai media promosi karena menawarkan banyak keuntungan (Rahadi \& Abdillah, 2013). (Siswanto, 2013) menuturkan bahwa media sosial menjadi media yang paling ampuh untuk dijadikan media promosi, bahkan media sosial juga digunakan sebagai alat pemasaran yang interaktif, pelayanan, dan membangun hubungan dengan pelanggan dan calon pelanggan. (Putri, 2016) meneliti mengenai hubungan iklan di media sosial dengan minat beli, dan hasil penelitian menunjukkan bahwa ada hubungan positif yang signifikan antara iklan di media sosial dengan minat beli konsumen. 
Pemilik akun Instagram dan Youtube tersebut adalah Laninka Siamiyono, seorang wanita muda penderita Rheumatoid Artritis. Rheumatoid Artritis sendiri adalah sebuah gangguan inflamasi kronis yang mempengaruhi sendi. Rheumatoid arthritis menyebabkan peradangan sendi akibat sistem kekebalan tubuh yang menyerang jaringannya sendiri (Ningsih, Novita, Fitriana, \& Sahrir, 2019). Radang sendi ini menimbulkan keluhan bengkak dan nyeri sendi, serta sendi terasa kaku. Akibat kelainan ini Laninka harus duduk di kursi roda dan tanganya tidak berfungsi sebagaimana kebanyakan orang sejak berusia 15 tahun. Sejak saat itu, Laninka adalah penyandang tuna daksa.

Laninka sempat mengalami putus asa dan keterpurukan selama 10 tahun hingga tak mau keluar rumah. Ia sempat malu dengan keadaan dan penampilanya hingga tak mau merawat diri dan tak peduli dengan penampilanya. Hingga suatu ketika, seorang teman Laninka datang ke rumah dan memberikan Laninka sebuah eyeliner. Awalnya, Laninka masih belum bisa menggunakan eyeliner tersebut. Laninka menggunakan eyeliner pemberian temanya tersebut dengan cara dibantu orang lain. Saat eyeliner terpasang pada wajahnya, Laninka merasa memiliki kepuasan sendiri dalam hatinya saat menggunakan benda tersebut. Lambat laun, Laninka belajar menggunakan eyeliner tersebut dan beberapa alat make up lainnya. Sejak saat itu Laninka memiliki ketertarikan terhadap dunia kecantikan dan tata rias. Kepiawaianya menggunakan make up meningkat seiring dengan kepercayaan dirinya yang meningkat. Ia pun sudah mulai percaya diri dan berani berinteraksi dengan dunia luar.

Kemampuan Laninka dalam mengaplikasikan make up ke wajahnya makin mumpuni. Hingga pada suatu saat ia memberanikan diri untuk mengunggah video tutorial make up pada akun Instagram-nya. Ternyata, unggahan tersebut mendapat respon positif dari pengguna Instagram. Video tersebut menjadi viral hingga menarik perhatian dari banyak beauty vlogger ternama seperti Tasya Farasya, Astari Budi, Fathi Nurma, dan Abel Cantika yang kemudian menyatakan kekagumanya pada Laninka serta memberi semangat dan juga membagikan unggahan tersebut kepada pengikutnya yang lain di mana pengikutnya berjumlah jutaan. Otomatis, unggahan ini menjadi sangat viral dan mendapat banyak perhatian serta respon positif dari khalayak pengguna Instagram.

Viralnya video ini tidak membuat Laninka tinggi hati. Ia justru berinisiatif untuk membuat wanita penyandang disabilitas lain untuk ikut menemukan rasa percaya dirinya. Laninka kemudian membuat gerakan 1000 lipstik untuk difabel pada akun instagram-nya. Gerakan tersebut berjalan dengan cara menerima donasi lipstick maupun uang yang nantinya juga akan dibelikan lipstick dari khalayak perngguna instagram dalam kurun waktu satu bulan yang kemudian akan dibagikan kepada penyandang difabel.

Ternyata di luar dugaan, gerakan ini kemudian kembali menjadi viral dan mengundang perhatian dari khalayak pengguna instagram termasuk yang kemudian ikut berpartisipasi dalam gerakan 1000 lipstick untuk difabel. Banyak sekali donasi lipstick yang datang dari pengikut Instagram dan penonton YouTube Laninka. Banyak khalayak yang tidak hanya ikut mendonasikan lipstick dan uang namun juga ikut 
mempromosikan gerakan ini. Lagi-lagi, gerakan ini mengundang perhatian para beauty influencer hingga artis papan atas untuk ikut menyumbangkan Lipstik. Beauty Influencer seperti Astariri, Alma Mestika, Fathin Nurma hingga selebgram seperti Rachel Vennya ikut menyumbang lipstick pada Gerakan 1000 Lipstick untuk difabel. Tidak hanya kalangan pengguna Instagram saja dan influencer saja yang ikut mendukung sertam menyumbakan lipstick pada gerakan ini. Beberapa merek Make Up ternama seperti Wardah, Make Over hingga Maybelline juga turut berpartisipasi pada gerakan ini. Maka dari itu, dalam waktu kurang dari seminggu Laninka dan team Gerakan 1000 Lipstick untuk difabel sudah dapat jauh melampaui target dan mendapat donasi lebih dari 3000 lipstick. Melihat antusiasme khalayak yang jauh di luar dugaan ini, Laninka dan tim memutuskan untuk sementara menutup pembukaan donasi dan berfokus membagikan Lipstick pada teman-teman wanita difabel.

Laninka bersama team 1000 Lipstick untuk difabel kemudian berkeliling ke beberapa Sekolah Luar Biasa (SLB) di sekitar Jakarta untuk membagikan lipstick sekaligus memberikan motivasi kepada para wanita penyandang disabilitas. Adapula beberapa event untuk penyandang disablitas yang didatangi Laninka dan tim Lipstick untuk difabel untuk memberi motivasi serta membagikan lipstick. Sedangkan untuk menjangkau teman-teman wanita yang menyandang disabilitas di luar kota, Laninka dan tim membuka pendaftaran untuk sukarelawan yang berkenan untuk membantu tim 1000 Lipstick untuk difabel membagikan lipstick pada wanita penyandang disabilitas yang ada di luar Jakarta.

Karena kisah yang sangat mengispirasi tersebut, Laninka diundang ke berbagai seminar disabilitas maupun kewanitaan sebagai pembicara untuk memberikan motivasi bagi para wanita penyandang disabilitas. Bahkan, beberapa kali juga Laninka diundang ke acara Talkshow yang disiarkan pada stasiun televisi nasional seperti Hitam Putih dan Kick Andy.

Sampai sekarang team 1000 Lipstick untuk difabel masih menerima donasi berupa lipstick atau uang yang nantinya akan dibelikan lipstick juga kemudian dibagikan ke teman-teman wanita penyandang disabilitas pada event-event disabilitas, Sekolah Luar Biasa maupun teman penyandang disabilitas yang menghubungi team 1000 Lipstick untuk Difabel melalui direct massage pada akun Instagram @lipstickuntukdifabel.

Penelitian terdahulu menunjukkan bahwa pencantuman kebutuhan dan asipirasi penyandang disabilitas disemua tahap manajemen bencana, khususnya perencanaan dan kesiapsiagaan, secara signifikan dapat mengurangi kerentanan mereka dan meningkatkan efektivitas usaha tanggap darurat dan recovery yang dilakukan pemerintah (Probosiwi, 2013).

\section{Metode Penelitian}

Penelitian ini menggunakan pendekatan metode penelitian kualitatif dengan menggunakan metodelogi studi literatur. Referensi didapat dari berbagai sumber seperti jurnal ilmiah, buku, artikel, laporan penelitian, objek dan situs internet yang mumpuni. Selain itu penelitian ini juga mengacu pada teori agenda setting. Penekanan utama dari 
teori agenda setting adalah bahwa isu-isu tersebut menitik beratkan pada berita yang hadir dan dianggap penting oleh publik. Dengan kata lain, agenda media menerapkan agenda yang dimiliki publik. Bertentangan dengan hukum konsekuensi minimal, ini merupakan pernyataan tentang efek kausal yang kuat atas komunikasi massa yang terjadi secara publik, yakni transfer atas sesuatu yang penting dari agenda media kepada agenda publik (McCombs \& Guo, 2014).

Teori agenda setting secara spesifik berawal dari penjelasan atas implikasi media atas perilaku dan tindakan politik selama tahun-tahun pemilu, yakni bagaimana media pemeberiitaan mengungkap dan memprioritaskan isu tertentu, dan mengatur agenda untuk publik. Media mungkin tidak akan sukses mendikte cara berpikir masyarakat, namun media secara baik berhasil memberitahu para pembacanya hal-hal apa saja yang harus menjadi perhatian mereka (Littlejohn \& Foss, 2009).

\section{Hasil dan Pembahasan}

Tentu saja yang dipahami dalam keterkaitannya dengan pembahasan ini adalah peran media massa dalam penyusunan agenda/acara/kegiatan seseorang. Media pemberitaan adalah jendela yang dimiliki masyarakat terhadap dunia yang berlangsung secara cepat dan merupakan pengalaman secara langsung, serta menentukan pemetaan kognisi kita terhadap dunia. Opini publik, bukan merupakan tanggapan kita terhadap lingkungan, melainkan terhadap pseudo-lingkungan, yakni sebuah kontruksi yang dibentuk oleh media pemberitaan (McCombs \& Guo, 2014).

Secara konseptual, kebutuhan individu untuk sebuah orientasi didefinsikan dalam dua konsep, yakni: relevansi dan ketidakpastian, yang mana berperan dan berjalan secara berangkai. Relevansi merupakan kondisi yang terdefinisikan oleh kondisi atas kebutuhan akan sebuah orientasi. Kebanyakan dari kita merasakan ketidaknyamanan psikologis dan butuh akan sebuah orientasi pada sejumlah situasi, lebih khusus pada ranah urusan publik, sebab kita tidak dapat menerima situasi tersebut menjadi hal yang relevan (McCombs \& Guo, 2014).

Analisis atas data-data yang terkait dengan relevansi ini didasarkan pada tiga dimensi, antara lain: 1) relevansi sosial: diukur berdasarkan skala irelevan/relevan dan tidak penting/penting, 2) relevansi personal: penting bagi saya/tidak penting bagi saya, menjadi perhatian saya/tidak menjadi perhatian saya, 3) relevansi emosional: membosankan/menarik, mengesankan/tidak mengesankan (McCombs \& Guo, 2014).

Sebagian besar pengaruh agenda setting merupakan produk jadi kebutuhan media untuk berfokus pada topik-topik berita setiap harinya. Dan fokus ketat terhadap isu-isu yang terkait media adalah pesan kuat kepada penonton tentang apa-apa saja topik yang penting untuk saat ini. Agenda setting mengarahkan atensi kita kepada tahapan formatif awal opini publik ketika isu terjadi dan melibatkan atensi publik, yang mana merupakan situasi yang berkonfontrasi dengan para jurnalis beserta tanggung jawab etis untuk memilih secara berhati-hati isu yang ada pada sebuah agenda (McCombs \& Guo, 2014).

Kebutuhan akan orientasi merupakan versi kognitif dari prinsip ilmiah "Alam Membenci Sebuah Kevakuman". Pada ranah urusan publik, kebutuhan individu akan 
orientasi lebih mungkin terjadi dan mengakibatkan seorang individu untuk mengikuti agenda dari media pemberitaan dengan kayanya informasi yang hadir. Konsep ini juga mengidentifikasi isu-isu yang bergerak dari agenda media menuju agenda publik, untuk disebutkan, isu-isu yang relevan dan tidak obstrusif. Jika isu yang tidak mengganggu ini dapat berkelindan dengan publik, kebutuhan akan orientasi berada pada tingkat sedang ataupun tinggi. Sebaliknya, isu-pada isu-isu yang obstrusif, kebutuhan akan orientasi mungkin hanya akan memuaskan pengalaman pribadi. Namun, beberapa pengalaman pribadi akan menciptakan kebutuhan lebih atas informasi dan publik akan berpaling menuju media massa untuk orientasi tambahan (McCombs \& Guo, 2014).

Kompetisi intens di antara isu-isu untuk ditempatkan pada agenda merupakan aspek penting pada proses ini. Pada beberapa momen, terdapat banyak isu yang memerlukan atensi publik. Tidak ada satu pun masyarakat beserta institusinya yang dapat hadir pada beberapa isu pada satu waktu bersamaan. Sumber-sumber atas perhatian ini terdapat pada media pemberitaan, di antara publik, dan pada varian institusi publik. Salah datu dari pandangan awal tentang agenda setting merupakan agenda publik yang berukuran terbatas (McCombs \& Guo, 2014).

Tegangan atas ukuran dari agenda publik ini dijelaskan oleh batas-batas sumber publik, yang mana batas ini menyertakan baik kapasitas waktu dan psikologis. Batasan atas kebanyakan ukuran agenda media menjadi lebih nyata, terbatasnya ruang pada media dan terbatasnya waktu dari penyiaran sebuah berita. Hal ini juga terjadi pada kasus situs internet, dengan kapasitasnya yang seolah tidak terbatas, perhatian publik menyediakan waktu yang mengatasi ketegangan ini. Keseluruhan tegangan pada agenda atas isu publik yang terjadi dalam masyarakat diringkas pada gagasan dari proses agenda setting sebagai permainan zero-sum yang mana bangkit dari sebuah agenda dan meluas pada isu-isu lainnya (McCombs \& Guo, 2014).

Masyarakat terlibat pada proses belajar terus-menerus tentang urusan-urusan publik. Respon mereka terhadap tentang isu apa yang paling penting merefleksikan pembelajaran media pada beberapa waktu belakangan. Dampak agenda setting yang sering menghasilkan proses ini dibentuk pada beberapa tingkatan dan dikarakteristikkan oleh pesan media dan karakteristik atas penerimaan atas pesan-pesan tersebut. Komunikasi massal, termasuk juga kebanyakan media sosial baru, merupakan proses yang mana terdapat pesan-pesan redundan yang terdiseminasi. Berbagai karakteristik atas pesan-pesan tersebut memengaruhi bagaimana orang-orang akan memerhatikan, setidaknya pada beberapa porsi atas sebuah konten (McCombs \& Guo, 2014).

Aspek-aspek baru atas teori agenda setting berkonsekuensi atas tindakan dan perilaku masyarakat yang biasanya dikendalikan oleh kognisi, yakni apa yang orang ketahui, pikirkan, dan percayai. Oleh karenanya, fungsi agenda setting atas media massa bermiplikasi secara potensial pada pengaruh masif dengan dimensi dan konsekuensi penuh yang harus diinvestigasi dan diapresiasi (McCombs \& Guo, 2014).

Efek agenda seting dari komunikasi massa memiliki implikasi signifikan melampaui gambaran yang tercipta pada pikiran masyarakat. Secara orisinil, domain tradisional atas agenda setting, relevansi isu publik, terdapat bukti yang menggeser 
relevansi atas isu-isu tersebut yang seringkali merupakan dasar dari opini publik tentang keseluruhan wacana publik. Pada gilirannya, relavansi urusan publik pada berita juga terkait dengan pegangan individu terhadap sebuah opini. Pada tingkatan kedua, relevansi atas atribut afektif berkaitan dengan gambaran kognisi publik atas representasi dan konvergensi dari sebuah perubahan formasi agenda setting (McCombs \& Guo, 2014).

Agenda publik memiliki dampak terhadap agenda media, penonton memperjelas posisinya kepada media (melalui rating, studi, riset pasar, dan pola konsumsi) mengenai apa yang mereka ingin saksikan dan baca, kemudian media tinggal meresponnya. Dengan kata lain, media merupakan sesuatu yang digerakkan oleh pasar dan dapat mengetahui hal apa yang menjual bagi penontonnya. Politisi dan humas juga berperan dalam menyusun agenda media, sehingga agenda media tersebut tidak terdapat kevakuman (Littlejohn \& Foss, 2009).

Media bukan sekadar penyampai informasi dan opini, sekalipun media tidak mampu mendikte pikiran publik, namun media berhasil memberitahu publik apa yang harus menjadi perhatiannya. Oleh sebab itu, realitas menjadi terlihat berbeda bagi masing-masing orang, bukan hanya tergantung dari ketertarikan personalnya, melainkan juga dari pemetaan yang telah dituliskan untuk publik oleh penulis, editor, penerbit, dan media yang dikonsumsi (Baran \& Davis, 2015).

Berdasarkan pengertian-pengertian di atas, dapat dikemukakan bahwa agenda setting theory membicarakan tentang peran besar media massa dalam menentukan agenda orang-orang yang terkena informasi tersebut. Masyarakat menjadi terbiasakan dengan berita-berita yang disampaikan media, sehingga menjadi bahan pembicaraan dalam pergaulan sehari-hari. Berita atau informasi yang disampaikan media tersebut bukan saja hanya sebagai ilmu atau pengetahuan bagi masyarakat, tetapi bahkan bisa mengubah gaya hidup, perilaku, ataupun sikap masyarakat.

Hal yang penting dari dampak dan konsekuensi agenda setting adalah priming, yakni perspektif yang membimbing opini publik tentang urusan publik, yang mana merupakan konsekuensi yang membawa dampak agenda setting dari media menuju inti dari arena opini publik. Media membentuk agenda dari sebuah objek dan mengatirbusikannya pada pikiran publik, dengan memberi atensi pada sebuah urusan dibandingkan urusan yang lainnya. Keterkaitan antara dampak agenda setting yang dihasilkan dari pentingnya sebuah isu atau elemen lainnya di antara publik, dan ekspresi tentang urusan publik secara spesifik ini disebut sebagai priming. Dasar psikologis atas konsep ini adalah perhatian selektif atas publik. Dengan kata lain, publik bergantung pada objek agenda yang relevan dan mengatribusikannya pada pikiran, dan agenda ini disusun oleh beberapa pertimbangan dan tingkatan sesuai kriteria yang dirumuskan media massal, sehingga terbentuklah opini publik (McCombs \& Guo, 2014).

Agenda setting beroperasi melalui proses priming, dan oleh karenanya melalui perhatian yang repetitif, media membuat beberapa isu menjadi fokus utama seseorang. Agenda setting terjadi karena media harus selektif dalam melaporkan sebuah berita, serta bagaimana harus melaporkannya. Yang publik ketahui tentang urusan sebuah 
negara, sebagian besar merupakan produk dari apa yang dirumuskan oleh media. Tingkatan media setting diidentifikasikan pada hal-hal berikut ini: penetapan isu umum yang penting (objek agenda setting) dan kemudian memutuskan bagian atau aspek apa yang dianggap menjadi penting (atribut agenda setting). Agenda setting pun juga berfungsi dalam proses tiga bagian: agenda media, agenda publik, dan agenda kebijakan (Littlejohn, S. W., Foss, K. A., \& Oetzel, 2017).

Priming merupakan gagasan yang didasari pada anggapan bahwa masyarakat tidak dapat memertimbangkan segala sesuatu yang mereka ketahui ketika mengevaluasi isu-isu yang komplek. Masyarakat justru tertarik pada hal-hal yang ringan untuk dipikirkan. Konsekuensinya, media memutuskan apa yang baik sebagai keputusan dan pilihan bagi permasalahan yang rumit. Ketika agenda setting berdampak pada peliputan isu tertentu, priming berfungsi untuk membuat sebuah keputusan atas isu tersebut (Baran \& Davis, 2015).

Sekalipun bukti menunjukkan bahwa generasi muda tidak mudah terekspos oleh media tradisional sebagaimana generasi yang lebih tua, dan juga signifikansi internet lebih dirasakan oleh generasi ini, terdapat juga dukungan kecil terhadap gagasan intuitif bahwa diversitas media akan berujung pada agenda publik bersama, sebagaimana kita mengetahuinya. Penggunaan media yang berbeda di antara generasi muda sekilas tidak memengaruhi efek agenda setting sama sekali (McCombs \& Guo, 2014).

Namun, temuan ini tidak serta-merta menolak bahwa terdapat pengaruh kuat media (e.g. Koran, penyiaran, dan situs). Jika ditinjau lebih luas, hal ini merupakan inti dari suara komunikasi yang mendefinisikan fabrikasi sosial yang terjadi pada masyarakat. Implikasi besar dari komunikasi dihasilkan dari proses terus-menerus atas keterlibatan masyarakat sipil. Aspek penting dari keterlibatan masyarakat sipil adalah jumlah besar dari kanal berita yang tersedia bagi publik. Pada tingkatan individual, sejumlah masalah dapat disebutkan oleh responden ketika mendapat pertanyaan tentang problem penting apa yang dihadapi oleh komunitas local dan secara signifikasn berkaitan dengan jumlah suara media yang terdapat pada komunitas tersebut (McCombs \& Guo, 2014).

Terdapat konsep agendamelding dalam teori agenda setting, yakni bagaimana orang-orang meminjam agenda dari beberapa media yang berbeda untuk menciptakan dan menemukan sudut pandang dari sebuah komunitas. Konsep ini melibatkan tiga elemen: 1) agenda setting media vertikal (televisi, radio), 2) agenda setting media horizontal (majalah, tabloid, dan situs), 3) preferensi personal (media sosial) (Littlejohn, S. W., Foss, K. A., \& Oetzel, 2017).

Fenomena ini dapat ditinjau dengan menggunakan teori agenda setting, Berdasarkan teori agenda setting, pemberitaan positif dan negatif media sosial terhadap kampanye yang dilakukan oleh @laninka di Instagram memberikan opini baru di mata publik. Sesuai dengan makna di dalam teori agenda setting bahwa apapun yang dipublikasikan di media sosial dan media massa, maka dapat memberikan informasi yang dianggap penting oleh publik. Sebaliknya juga apapun yang tidak dipublikasi oleh media sosial maka juga tidak dianggap penting oleh publik. Karena fungsi dari media 
sosial menurut teori ini adalah sebuah teori yang dapat memberikan pandangan baru di publik atau memunculkan opini baru pada publik.

Kampanye yang dilakukan @laninka dipublikasikan di platform media sosial Instagram yang mana akhirnya memberikan opini baru atau pandangan baru di masyarakat dengan cara kampanye lipstik untuk disabilitas yang mana lipstick tersebut diperoleh dari pembukaan donasi beberapa tokoh influencer dan brand make up ternama di indonesia. Tujuan dari kampanye @laninka yaitu untuk mengembalikan kepercayaan diri para penyandang disabilitas sehingga juga dapat mematahkan stereotipe di masyarakat awam bahwa cantik tidak harus sempurna.

kampanye yang dilakukan@laninka tersebut sejak Sepetember 2018 hingga saat ini membawa pengaruh yang cukup besar. Tidak hanya kampanye di sosial media saja, @laninka juga mempunyai kanal Youtube yang berisi konten tentang make up tutorial yang dapat memotivasi khalayak banyak. Sesuai dengan kampanye yang dilakukan @laninka di instagram berikut lampiran aktivitas dari kampanye tersebut:

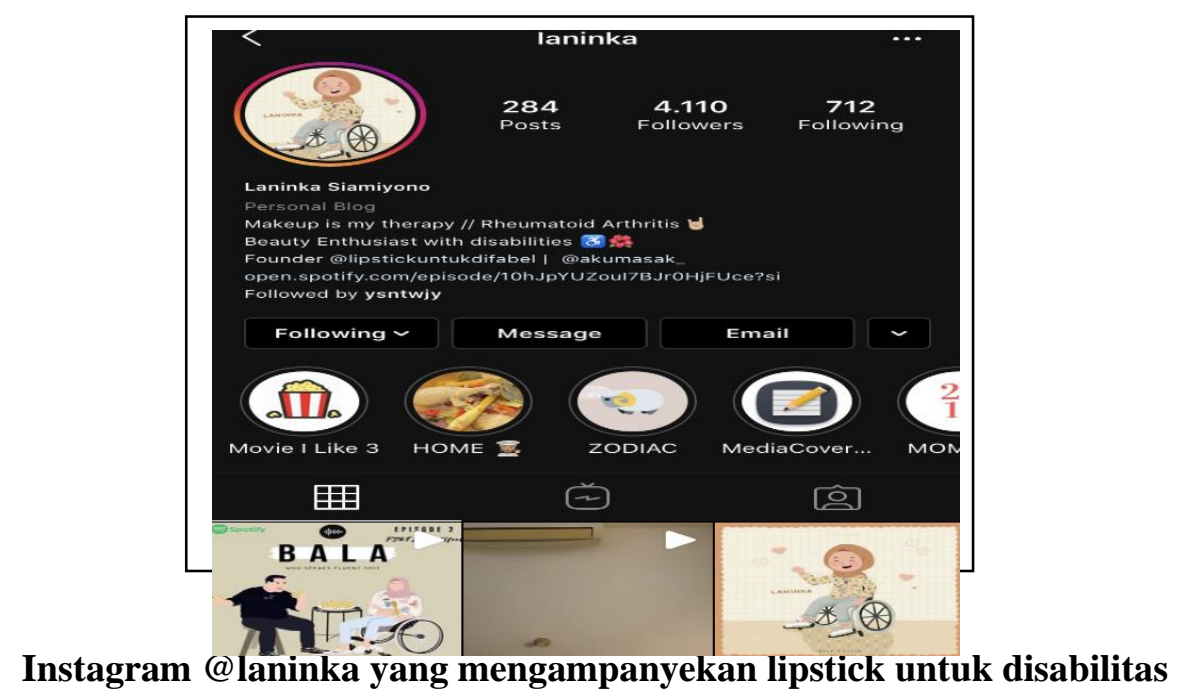

Pada gambar 1 ditampilkan profil Instagram penggagas dari kampanye lipstick untuk disabilitas juga berisi tentang unggahan yang bersangkutan dengan hal hal yang berhubungan dengan donasi.

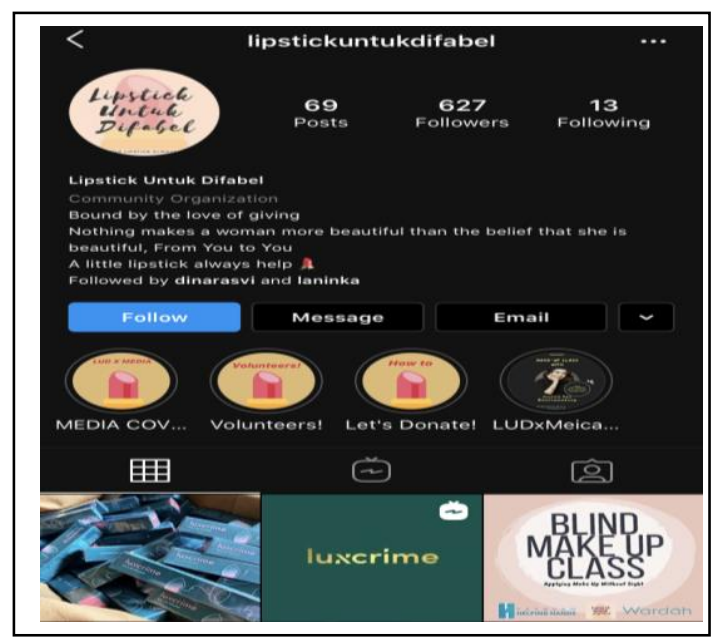




\section{Gambar 2 \\ akun Instagram @lipstickuntukdifabel}

Pada gambar 2 ini, owner @laninka membuat akun instagram dari kampanye yang dilakukannya itu di instagram (@lipstickuntukdifabel), yang bertujuan untuk mengumpulkan volunteer dalam melaksanakan kampanye yang dilakukannya tersebut. Secara tidak langsung kampanye ini membutuhkan dukungan dari orang lain. Dengan kampanye yang dilakukan oleh pihak @laninka dan team memang memiliki tujuan untuk memberikan motivasi dan semangat baru untuk para penyandang disabilitas di seluruh Indonesia maupun di seluruh dunia melalui unggahannya di sosial media instagram dan Youtube.

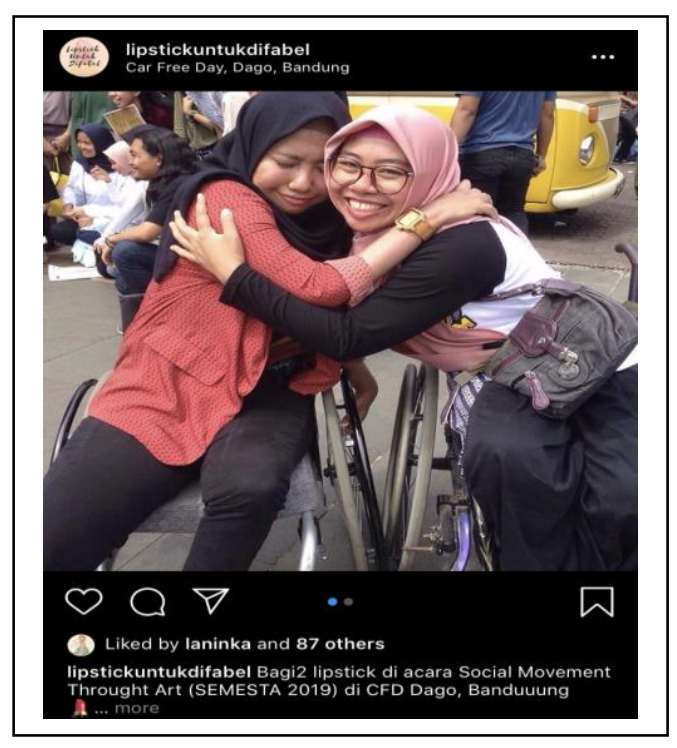

\section{Gambar 3 \\ pembagian lipstick di acara Social Movement Throught Art (SEMESTA 2019), Bandung}

Pada gambar 3 ini @laninka sebagai pencetus dari kampanye lipstick untuk disabilitas melakukan aksi sosial untuk para teman-teman yang menyandang disabilitas juga adalah bentuk saling mendukung dan memberi motivasi untuk teman-teman disabilitas yang menggambarkan saling mendukung satu sama lain.

Komunikasi yang berhasil secara efektif, informasi merupakan tanda yang dikonstitusikan secara konteks pada perspesi dan konsepsi penerima pesan. Informasi harus dirumuskan sebagai objek yang dapat dipahami dan mengandung pesan yang bermakna. Proses dekode dan enkode menjadi penting ketika berhadapan dengan subjektivitas dan agensi yang terlibat. Komunikasi, sekalipun hanya berjalan satu arah dan bertindak sebagai penerima pesan, oleh karenanya merupakan tindakan yang aktif (Schandorf, 2019). 
Pengumpulan donasi lipstick untuk difabel ini juga mampu membentuk opini publik terhadap orang-orang dengan disabilitas. Dalam rangka pembentukan opini publik, penting untuk diingat bahwa beberapa teoritikus tidak memercayai kemampuan massa dalam menerima dan mengolah informasi. Oleh karenanya, perubahan drastis sistem dibutuhkan guna membantu khalayak luas dalam mengahadapi sebuah propaganda. Publik sangat rentan terhadap propaganda, beberapa mekanisme dan agensi untuk melindungi publik. kontrol terhadap media diperlukan untuk menempatkan siapa saja yang tepat untuk menerima jenis informasi tertentu (Baran \& Davis, 2015).

Opini publik berpijak pada pendirian masyarakat sebagai anggota kelompok sosial mengenai suatu persoalan. Definisi ini dengan gamblang meyingkap aspek-aspek apa saja yang secara positivistik dibuang dari konsep opini publik historis selama dekadedekade perkembangan teoretis dan di atas semuanya, kemajuan metodologis empirisnya. Mula-mula 'publik' sebagai subjek opini publik disamakan dengan 'massa', lalu dengan 'kelompok', kemudian dengan substratum sosial-psikologis bagi proses komunikasi dan interaksi antara dua individu atau lebih. Kelompok diabstraksikan dari serangkaian kondisi sosial dan historis, serta alat-alat institusional, dan tentunya dari jaring-jaring fungsi sosial yang dulu pernah jadi penentu strata masyarakat yang bergabung membentuk publik yang berdebat (Habermas, 2007).

Dampak yang dapat ditimbulkan media dari proses agenda setting cukup beragam. Salah satu dampak yang hadir dari proses agenda setting ini adalah munculnya sebuah gerakan sosial. Melalui gerakan sosial ini, kelompok masyarakat bertindak secara kolektif untuk melihat sebuah solusi yang dapat diimplementasikan terhadap sebuah permasalahan sosial (Dearing, J. W., \& Rogers, 1996).

Pengorganisasian orang-orang dengan disabilitas dapat meningkatkan kesadaran masyarakat guna menghilangkan stigma bahwa orang dengan disabilitas merupakan penghalang atau lebih jauh lagi tindakan negatif yang berujung pada tercabutnya hakhak orang dengan disabilitas. Hanya dengan cara pengorganisasian ini, orang-orang dengan disabilitas dapat merasa bangga terkait siapa diri mereka, dan dapat menerima kekurangan diri sebagai hal yang harus diterima bukan untuk ditolak atau dihilangkan (Campbell, Oliver, \& Oliver, 1996).

Memberdayakan orang dengan disabilitas pada sebuah gerakan tentu memiliki dampak positif pada perubahan sosial. Namun, upaya ini juga harus bisa lepas dari campur tangan pasar untuk menciptakan citra bahwa sebuah brand juga memerhatikan kondisi orang-orang dengan disabilitas. Di satu sisi pasar memang memberdayakan orang dengan disabilitas dengan cara melibatkan mereka pada berbagai hal, namun di sisi lain hal ini menjadi masalah karena sistem pasar menciptakan bentuk instrumen kesetaraan baru: kemerdekaan untuk diapropriasi oleh budaya konsumen. Isu-isu diversitas macam ini memang dapat membangkitkan sensibilitas liberal, dengan membuat konsumen merasa telah berbuat baik karena mengonsumsi komoditas yang diproduksi oleh perusahaan yang peduli terhadap kondisi disabilitas (Garland-Thomson, 2011). 
Bila ingin memadatkan dalam satu kalimat apa yang dinamakan ideologi budaya massa, maka jargon "jadilah seperti apa yang kamu inginkan" akan selalu digaungkan dan menjadi sebuah pemujaan terhadap reduplikasi dan justifikasi semua urusan yang ada sembari mengabaikan semua transendensi dan kritisisme (Adorno, 2002).

Pemberdayaan terhadap orang dengan disabilitas pada satu sisi dapat mempromosikan otonomi dan determinasi diri, namun di sisi lain, secara implisit beberapa pemberdayaan model ini berarti mengamini pondasi pasar bebas. Hal ini dikarenakan berarti memosisikan orang dengan disabilitas sebagai konsumen yang menerima perlakuan yang setara dari pasar. Kemampuan untuk mengakses pasar ini tentu akan berbeda jika dihadapi oleh orang dengan disabilitas yang hidup pada kondisi kemiskinan. Akses terhadap pasar dengan diikuti label pembebasan secara sosio-politis ini hanya bisa dinikmati oleh orang yang memiliki keistimewaan, kemampuan, dan kemauan untuk membeli (Russell \& Malhotra, 2002).

Memahami disabilitas beroperasi pada kategori identitas dan konsep kultural berarti memahami posisi disabilitas bukan kondisi natural atas inferioritas, ketidakmampuan dan kesialan nasib. Sebagaimana gender dan ras, disabilitas merupakan narasi dan fabrikasi kultural tentang tubuh. Oposisi biner abilitas/disabilitas menciptakan subjek berdasarkan pembedaan yang ditinjau dari segi tubuh, dan hal semacam ini lebih bersifat ideologis ketimbang biologis. Parahnya, pandangan ini telah masuk dalam formasi budaya dan lebih-lebih melegitimasi ketimpangan hak yang terjadi pada masyarakat (Garland-Thomson, 2011).

Kebanyakan orang yang hidup tanpa disabilitas mengaitkan sebuah kerusakan fungsi fisik pada sebuah kondisi disabilitas, hal ini merupakan dampak dari medikalisasi atas tubuh. Menjadi seorang yang hidup dengan disabilitas adalah berarti menempuh pengalaman atas beberapa permasalahan tubuh dan/atau pikiran sehingga membuat distingsi atas orang dengan disabilitas dan orang tanpa disabilitas. Dengan memahami pengalaman ini, seseorang yang hidup dengan disabilitas akan memaknai sebuah "alat bantu" bukan sekadar alat yang dapat menunjang fungsi tubuhnya, melainkan sebagai entitas yang telah menubuh dan menjadi bagian dari tubuh orang tersebut (Sheppard, 2020)

Perubahan signifikan harus terjadi guna mendukung hajat hidup orang-orang dengan disabilitas. Pemberdayaan secara kampanye media memang penting guna meningkatkan kesadaran publik terkait kondisi yang dialami orang-orang dengan disabilitas. Namun, tuntutan atas ketersediaan fasilitas umum yang sesuai dengan kondisi orang dengan disabilitas semacam jalur kursi roda, pintu yang lebih lebar, dan lain sebagainya juga harus ditingkatkan. Belum lagi jika berbicara tentang bangunan atau fasilitas yang dimiliki secara pribadi (e.g. mal, klub, rumah ibadah, dsb), tentu belum meletakkan prioritas atas ketersediaan fasilitas yang mendukung kondisi orang dengan disabilitias (McNeese, 2014).

Pentingnya gerakan yang membawa kepentingan orang dengan disabilitas bukan hanya penting bagi orang-orang yang hidup dengan disabilitas. Semakin hari, siginfikansi gerakan ini semakin besar, sebab gerakan yang membawa kepentingan 
orang dengan disabilitas dapat menjadi pusat dari gerakan, dan ini bukan terkait legasi macam apa yang akan ditinggalkannya, namun lebih kepada bentuk-bentuk relasi sosial baru seperti apa yang dapat muncul dari proses kreasi gerakan ini (Campbell et al., 1996).

\section{Kesimpulan}

Penelitian ini membahas bagaimana agenda setting media memengaruhi opini publik. Kampanye lipstick untuk disabilitas digunakan sebagai contoh bagaimana peranan media dalam memengaruhi opini publik di masyarakat. Meski demikian, analisis dalam tulisan ini hanya didasarkan pada pengamatan melaui instagram dari @laninka, bukan pada keketatan metodologi. Proses demokratisasi media dan politik yang berlangsung pasca Orde Baru mestinya bisa membuka area studi yang lebih luas dan menantang. Utamanya, jika penelitian-penelitian tersebut diorientasikan untuk menguji atau mengembangkan perspektif teoretik yang selama ini didiskusikan di ranah akademis. Studi-studi dampak media yang selama ini masih menimbulkan silang pendapat kiranya bisa menjadi bahan dasar pijakan bagi studi-studi lebih lanjut dengan mengambil kasus-kasus yang terjadi dalam sistem dan komunikasi politik di Indonesia. Studi tersebut juga bisa memasukkan fenomena yang terjadi dalam media interaktif. Kampanye lipstick untuk disabilitas ini memperlihatkan bahwa media interaktif mampu mendorong gerakan sosial yang lebih luas. Oleh karena itu, dalam konteks opini dan kebijakan, kehadiran media interaktif bisa menjadi bahan kajian lanjutan yang tak kalah menarik. 


\section{BIBLIOGRAFI}

Adorno, Theodor W. (2002). Dialectic of enlightenment: Philosophical fragments.

Balakrishnan, Bamini K. P. D., Dahnil, Mohd Irwan, \& Yi, Wong Jiunn. (2014). The impact of social media marketing medium toward purchase intention and brand loyalty among generation Y. Procedia-Social and Behavioral Sciences, 148, 177185.

Baran, S., \& Davis, K. (2015). Mass communication theory: Foundations, ferment, and future Boston. MA: Wadsworth Cengage Learning.

Campbell, Jane, Oliver, Mike, \& Oliver, Michael. (1996). Disability politics: Understanding our past, changing our future. Psychology Press.

Dearing, J. W., \& Rogers, E. M. (1996). Agenda-Setting. California: Sage Publications.

Garland-Thomson, Rosemarie. (2011). Integrating disability, transforming feminist theory. NWSA Journal, 1-32.

Habermas, Jurgen. (2007). Ruang Publik: Sebuah Kajian tentang Kategorisasi Masyarkat Borjuis, Yudi Santoso (penerjemah). Bantul: Kreasi Wacana Bantul. Hal, 44-66.

Indika, Deru R., \& Jovita, Cindy. (2017). Media sosial instagram sebagai sarana promosi untuk meningkatkan minat beli konsumen. Jurnal Bisnis Terapan, 1(01), $25-32$.

Littlejohn, S. W., Foss, K. A., \& Oetzel, J. G. (2017). Theories of Human Communication (11 ed.). Long grove: Waveland Press.

Littlejohn, Stephen W., \& Foss, Karen A. (2009). Encyclopedia of communication theory (Vol. 1). Sage.

McCombs, Maxwell E., \& Guo, Lei. (2014). Agenda-setting influence of the media in the public sphere. The Handbook of Media and Mass Communication Theory, 251268.

McNeese, Tim. (2014). Disability rights movement. Abdo.

Ningsih, Yunita Sofia, Novita, Novita, Fitriana, Alfina N., \& Sahrir, Dede Cahyati. (2019). Pengaruh Bee Venom Acupuncture (Bva) Terhadap Penyakit Neuropatik Dan Autoimun. Prosiding SNPS (Seminar Nasional Pendidikan Sains), 35-39.

Probosiwi, Ratih. (2013). Keterlibatan Penyandang Disabilitas dalam Penanggulangan Benca. Jurnal Dialog Dan Penanggulangan Bencana, 4(2), 77-86.

Putri, Citra Sugianto. (2016). Pengaruh media sosial terhadap keputusan pembelian konsumen cherie melalui minat beli. Jurnal Manajemen Dan Start-Up Bisnis, 1(5), 
Dinar Asvi Nurjannah, Yasinta Putri Wijaya dan Fakri Reza Kamrang

$594-603$.

Rahadi, Dedi Rianto, \& Abdillah, Leon Andretti. (2013). The utilization of social networking as promotion media (Case study: Handicraft business in Palembang). ArXiv Preprint ArXiv:1312.3532.

Russell, M., \& Malhotra, R. (2002). Disability and capitalism. Socialist Register, 211228.

Schandorf, Michael. (2019). Communication as Gesture: Media (tion), Meaning, \& Movement. Emerald Group Publishing.

Sheppard, A. (2020). So. Not. Broken. In A. Wong (Ed.), Disability Visibility: TwentyFirst Century Disabled Voice (p. 146). New York: Vintage Books.

Siswanto, Tito. (2013). Optimalisasi sosial media sebagai media pemasaran usaha kecil menengah. Liquidity, 2(1), 80-86.

Untari, Dewi, \& Fajariana, Dewi Endah. (2018). Strategi Pemasaran Melalui Media Sosial Instagram (Studi Deskriptif Pada Akun@ Subur_Batik). Widya Cipta: Jurnal Sekretari Dan Manajemen, 2(2), 271-278. 